\title{
STARZENIE SIĘ W KULTURZE MŁODOŚCI. WYBRANE STRATEGIE OBRAZOWANIA PÓŹNEJ DOROSŁOŚCI W REKLAMIE
}

\author{
ILONA ZaKowicZ \\ ilona.zakowicz@wp.pl
}

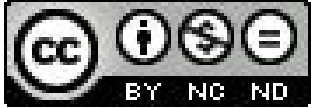

\begin{abstract}
"Starość została usunięta z wyobraźni zbiorowej.
Nieprzystające do faustycznych aksjomatów wspótczesności zwiotczate ciała strasza już tylko w domach spokojnej starości. W świecie kultury masowej króluje młode, najlepiej nagie i jędrne ciato: "Młodości wiecznie naga! Nagości wiecznie młoda!".

D. Czaja ${ }^{1}$
\end{abstract}

Swoisty renesans starości, dotąd jedynie przeczuwany, powoli, lecz sukcesywnie staje się faktem. Możemy wręcz zaryzykować twierdzenie, iż w pewnym sensie nastaje „moda na starość”. Współcześnie wiele się o niej mówi, zarówno w kontekście gospodarczym, ekonomicznym, społecznym, kulturowym, jak i demograficznym. Budzi zainteresowanie w kręgach akademickich, jak i szeroko rozumianej opinii publicznej. Jednym słowem, jak zauważa Jean Pierre Bois - starość robi dziś furorę - starość jest wręcz wszechobecna². Zjawisku owej popularności nie towarzyszy jednak jakościowa zmiana podejścia do starości i osób starszych - przeciwnie, staje się ona tematem wstydliwym i w pewnym sensie kłopotliwym. Traktowana jak choroba, czy też specyficznego rodzaju kara za niewystarczającą troskę o ciało, bywa spychana na margines.

Starość, jak wiadomo, jest tym etapem w życiu człowieka, który charakteryzuje się niezwykle wysokim poziomem indywidualizacji. Dlatego też, chcąc uchwycić jej specyfikę należy się przyglądać swoistości percypowania, opisywania i przedstawiania tejże, pamiętając jednocześnie, iż wymyka się ona wszelkim uogólnieniom. Starość, pomimo iż odwieczna i nieunikniona, obrosła grubą warstwą stereotypów i błędnych przekonań, efektem których jest ujmowanie tego okresu życia jako nieatrakcyjnego. Etapu, w którym dominuje „przewaga strat nad zyskami”, dają o sobie znać różnego rodzaju defekty, umiejscawiane przede wszystkim w ciele. Nie sposób nie zauważyć, iż starość nadmiernie często redukowana jest do cielesności, utożsamiana z menopauza, andropauza, klimakterium. Z premedytacją lokowana w kontekście niezliczonych schorzeń, dolegliwości i chorób (a zatem przypadłości przekształcających ciało w bombę z opóźnionym zapłonem, swoistą puszkę Pandory, która, choć przez lata szczelnie zamknięta, wraz z ich upływem i nadejściem starości, staje się źródłem wielu zmartwień). Starość jawi się więc w pewnym sensie jako „przekleństwo” człowieka zamkniętego w klatce niedołężniejącego ciała. Konsekwencją ujmowania starości wyłącznie w optyce cielesności jest uproszczony, zredukowany wyłącznie do zdrowia i wizerunku obraz starości, przyczyniający się do traktowania późnej dorosłości jak wstydliwej choroby, którą należy ukrywać bądź leczyć. Przypadłości, z którą dla komfortu psychicznego i estetycznego społeczeństwa, nie należy się afiszować - przeciwnie, powinno się ją „ukrywać", „zakrywać”, tak jak chowa się zużyte i niemodne już stroje z minionej epoki. Ciało człowieka starego bywa zatem traktowane jako „,niewidzialne", jest nieakceptowane i dlatego też, w pewnym sensie, „przezroczyste”.

1 D. Czaja, Reklamowy smak raju: między archetypem i historia, [w:] tenże (red.), Mitologie popularne, Kraków 1994, s. 149.

2 J. P. Bois, Historia starości od Montaigne’a do pierwszych emerytur, Warszawa 1996, s. 11. 
Co niezwykle interesujące, starzenie się ograniczone wyłącznie do cielesności i wizerunku, przestaje być traktowane jako zjawisko naturalne. W efekcie tego, zmiany pojawiające się na powierzchni ciała zaczynają być uznawane za swoiste zaniedbania. Wszelkiego rodzaju syndromy starzenia się, szczególnie zaś te, które wpływają na wizerunek, uznawane są za nieakceptowalne - nie przystające do idei „estetyzacji życia codziennego" - w konsekwencji więc coraz agresywniej się z nimi walczy. Warto wskazać, iż niepokojące słowo „walczyć” nie zostało w tym miejscu użyte przypadkowo. Analiza przekazów medialnych, szczególnie zaś pojawiających się w prasie kobiecej (bądź internecie) reklam kosmetyków, pozwala na sformułowanie wniosku, iż nomenklatura, jaką posługują się środki masowego przekazu w odniesieniu do starzejącego się ciała, oscyluje wokół terminów odwołujących się do agresji, władzy i sprawowania kontroli. Jest to język opresji nawołującej do swoistej autoagresji, celem której jest idealny wizerunek. Przykładów sformułowań, które zachęcają do dyscyplinowania starzejącego ciała, należy się doszukiwać przede wszystkim w reklamach kosmetyków, „stworzonych, aby walczyć z pierwszymi oznakami starzenia się skóry" ${ }^{\prime 3}$. Kosmetyki te bowiem „codziennie walczą z 7 oznakami starzenia się skóry"4 - jeżeli jednak i to nie pomoże, warto zastosować „silnie odmładzający zabieg, który wykorzystuje dobroczynne właściwości kawioru” ${ }^{5}$, ponieważ „nigdy nie jest za późno na wypowiedzenie wojny zmarszczkom, nawet tym najgłębszym!"”6.

Twórcy reklam, czego nie sposób nie zauważyć, coraz agresywniej zabiegający o klientów, w XXI w. odnaleźli w osobach starszych klienta wręcz idealnego. Rozpowszechniając przekonanie, iż atrakcyjny wygląd jest serum na wszelkie dolegliwości, stworzyli podatny grunt dla rozwoju ogromnych korporacji, wzbogacających się na lękach i frustracjach tych, którzy nie godzą się na wizerunek „przyprószony siwizną”. Groźba „niezauważalności” w przestrzeni publicznej, marginalizacji, czy też społecznej nieakceptacji - wszystko to sprawia, iż seniorzy podejmują trud modelowania wizerunku na kształt i podobieństwo standardów, oczekiwań i wzorów lansowanych przez społeczeństwo. Konieczność ciąłłego aktualizowania własnej cielesności, jej permanentna redefinicja, nie należy jednak do zadań najłatwiejszych. Przeciwnie, wszelkiego rodzaju zabiegi mające na celu „odzyskanie ciała utraconego" przez starzenie się, wzmacniają poczucie nieadekwatności i zagubienia. Owa nieadekwatność zasadza się bowiem na zaprzeczaniu starości, poszukiwaniu coraz atrakcyjniejszych sposobów zarządzania cielesnościa, przekształcaniu ciała w przestrzeń otwartą i plastyczną - podatną na wszelkiego rodzaju zmiany i sugestie. Wizerunek nie jest zatem współcześnie kwestią indywidualnego wyboru, lecz przymusu wzmacnianego i utrwalanego przez panteon idealnych obrazów ciał zamieszkujących kolorową odmłodzoną wiecznie atrakcyjną krainę młodości i szczęśliwości, krainę wykreowaną przez massmedia dla wizualnej przyjemności oglądających.

Ciało jest powierzchnia, na której najwcześniej dostrzegamy symptomy starzenia się. To ono, jako pierwsze, sygnalizuje, że młodość i uroda - będące dla współczesnego homo aestheticus wartościami nadrzędnymi - przemija. Pojawiają się pierwsze zmarszczki, siwe włosy, przebarwienia skóry, a wraz z nimi niepokój, u podstaw którego tkwi nie tylko obawa przed starzeniem się organizmu i śmiercia, ale także uzasadniony lęk przed zepchnięciem na margines. Manifestujący się wprost proporcjonalnie do upływu czasu strach, może być różnorodnie interpretowany. Ujawniając się w wielu rozmaitych kontekstach: społecznym, kulturowym, ekonomicznym, gospodarczym, staje się uczuciem wręcz dominującym. Uczuciem, które przenika wiele sfer, w efekcie czego wpływa na jakość życia osób starszych i ich sposób doświadczania świata.

3 http://www.avene.com.pl/dermokos.php?dnavi=6\&pm=p-ystheal\&ind=0, 20.02.2012.

http://ibeauty.pl/artykuly,146,148,2298, polecamy-na-prezent-zestawy-olay-total-effects, 20.02.2012.

$\mathrm{http}: / /$ www.cogiel-medicalspa.pl/oferta/pielegnacja-ciala/, 20.02.2012.

http://frownies.pl/frownies.html, 20.02.2012. 
Niejako „wdrukowany” w umysły ludzi starzejących się strach, wzmacniany przez owładnięte „kultem młodości” media masowe, przyczynia się do swoistej eskalacji poczucia zagrożenia, u podstaw którego tkwi zarówno obawa przed zniknięciem z pola społecznej widzialności, jak i lęk przed utratą dotychczasowego miejsca w społecznej stratyfikacji. Zasadnym zatem wydaje się być twierdzenie Georgesa Minoisa, iż starość to pojęcie, „,które najczęściej wzbudza dreszcz, słowo wypełnione niepokojem, słabościa, a czasem lękiem"”7. Będąc pojęciem mało precyzyjnym, słowem, którego znaczenie nadal pozostaje niejasne, wycinkiem rzeczywistości o trudnych do określenia zarysach od pokoleń wywołuje rozmaite, niejednokrotnie wręcz sprzeczne emocje, co zdaje się potwierdzać obserwowany współcześnie wzrost zainteresowania tym etapem życia, zarówno w mediach masowych, polityce, jak i opinii publicznej. Z uwagi na wzrost udziału osób w podeszłym wieku w ogólnej liczbie ludności społeczeństw zachodnich, seniorzy stają się grupą coraz uważniej „oglądaną" zarówno przez badaczy reprezentujących różne dziedziny wiedzy, jak i producentów dóbr i usług, którzy coraz wyraźniej dostrzegaja, iż w osobach starszych tkwi lekceważony do niedawna potencjał konsumpcyjny 9 .

Zdaniem J. P. Boisa seniorów należy uznać za pokolenie, które sztucznie zostało rozdzielone na: „zręcznie utworzona, dynamiczną formułę trzeciego wieku” („drugą młodość” sześćdziesięciolatków) oraz starość prawdziwa, „,którą przesunięto do czwartego wieku, zaczynającego się około osiemdziesiątki"10, i która w mediach masowych była dotąd niemal programowo pomijana. O starości wiele się współcześnie mówi i pisze, jej wizerunki pojawiają się $\mathrm{w}$ telewizji, filmach, czasopismach, reklamie. Seniorzy stają się „zauważalni” w przestrzeni publicznej, nie stanowią już specyficznego rodzaju „podkategorii” społecznej, w tak zwanym wieku poprodukcyjnym. Przeciwnie, stają się stałymi bywalcami kawiarni, kin, salonów urody, klubów tanecznych i wielu innych miejsc, które, jak można przypuszczać, będą dostosowywać swoje oferty do wymogów i oczekiwań starzejącego się społeczeństwa. Prawdą jest, iż seniorzy, z racji swej liczebności, wywierają coraz większy wpływ na kształt życia społecznego, nie zmienia to jednak faktu, iż zakorzenione w umysłach wielu Europejczyków stereotypy na temat starości i osób starszych nadal funkcjonują a co więcej „mają się dobrze". Powielane i wzmacniane przez środki masowego przekazu, zyskują rangę swoistych aksjomatów, które, w sposób wręcz niezaprzeczalny, wpływają na niekorzystne strategie obrazowania okresu późnej dorosłości, a w efekcie ich marginalne miejsce w społeczeństwie ${ }^{11}$.

Nie jest przesadnie odkrywczą teza, iż żyjemy w społeczeństwie zdominowanym przez „kult młodości” i „terror piękna”, przejawem którego są upowszechniane na szeroką skalę wizerunki ciał młodych, zadbanych, pięknych i atrakcyjnych, zdyscyplinowanych i przetworzonych, przypominających w pewnym sensie dzieła sztuki. Ciał, których wizerunek jest nieprzypadkowy - przeciwnie, wykreowany i zmodyfikowany do granic możliwości. Granic, które wyznacza ciało i społeczeństwo nieustające w poszukiwaniu coraz wymyślniejszych wyobrażeń tego, co Grecy zwykli nazywać soma. Jak słusznie zauważa Wojciech Klimczyk, „ponowoczesność umieszcza ciało w centrum zainteresowania"12, w efekcie czego staje się ono swoiście rozumianym obszarem wpływów społeczno-kulturowych. Jego wizerunki, czego nie sposób nie dostrzec, są wszechobecne. Reprodukowane bez końca

7 G. Minois, Historia starości. Od antyku do renesansu, Warszawa 1995, s. 11.

8 Tamże.

9 Zwiększeniu uległa ilość reklam, produktów i usług dla osób starszych: telefony, kosmetyki, produkty bankowe, ubezpieczeniowe.

10 J. P. Bois, Historia..., dz. cyt., s. 11.

11 Do stereotypów, jakie funkcjonują w polskim społeczeństwie, należą m.in. poglądy, iż osoby starsze są ubogie, schorowane, społecznie nieprzydatne, nie są: aktywne, skłonne do zmian, starość natomiast jest etapem w życiu człowieka nieatrakcyjnym, zdominowanym przez samotność i choroby.

12 W. Klimczyk, Erotyzm ponowoczesny, Kraków 2008, s. 99. 
w formie fotografii, reklam, dzieł sztuki, stają się symbolem wspomnianego „terroru piękności”, zasadzającego się na promowaniu ciał młodych, zdrowych, dynamicznych i estetycznie atrakcyjnych. Obserwowany współcześnie specyficzny rodzaj obsesji - a jest nią „obsesja ciała” - przyczynia się więc do zmiany statusu ciała zarówno w kulturze, jak i społeczeństwie. Staje się ono - jak dostrzega Zygmunt Bauman - „w pierwszym rzędzie organem konsumpcji i miarą jego należytego stanu jest zdolność wchłonięcia i zasymilowania wszystkiego tego, co społeczeństwo konsumpcyjne ma do zaoferowania"13. W ten sposób soma staje się w pewnym sensie instrumentem doświadczania świata, dzięki któremu współczesny człowiek „przeżywa świat konsumując go"114. Specyficznego rodzaju konsumpcja, jakiej dopuszcza się soma, może być oczywiście rozmaicie interpretowana, warto jednak pamiętać, iż "konsumujące” ciało samo także podlega ",konsumpcji” (jest „,konsumowane" przez inne ciała), stając się tym samym swoistym "towarem" uwikłanym w sferę wolnego rynku ${ }^{15}$.

Soma jest złożonym konstruktem społeczno-kulturowym i jako takie „powinno" się zaadaptować do panujących w określonym czasie norm i zasad, jeżeli bowiem nie jest $\mathrm{w}$ stanie "dopasować się do kulturowych wymogów, przynosi cierpienie i frustrację, związaną ze społeczną marginalizacją"16. Owo dostrajanie się do panujących wymogów dotyczy w głównej mierze kobiet, jak zauważa Edyta Zierkiewicz i Izabela Kowalczyk: wygląd stał się „podstawowym czynnikiem definiującym tożsamość kobiety. Kobiety są uczone patrzeć na siebie jako na obiekty spojrzeń dla innych"17. Każda kobieta czuje się zatem $\mathrm{w}$,jjakiś sposób uczestniczką konkursu piękności, $\mathrm{w}$ którym rywalkami są wszystkie inne kobiety. Nieważne, jak mało znaczące dla jej dążeń, jak nieadekwatne wobec jej uzdolnień i predyspozycji, czy też jak śmieszne jest porównywanie, kobiety są zawsze porównywane jedna $\mathrm{z}$ drugą i zawsze okazuje się, że mają jakieś braki”18. $Z$ tej też przyczyny nie sposób nie ulec wrażeniu, iż firmy, korporacje, koncerny - handlując marzeniami o idealnym wizerunku - podejmują coraz śmielsze próby kolonizowania wyobraźni konsumentów obrazami ciał idealnych, a wszystko to dokonuje się za pomocą mniej lub bardziej wyrafinowanych technik, autorami których są specjaliści do spraw marketingu i reklamy. Ci współcześni alchemicy - poszukujący i odkrywający lekarstwa na wszelkie dolegliwości, w tym także starość, która traktowana jest jako specyficzna, choć nieuleczalna choroba. Warto dodać, iż na tym zuchwałość tychże $\mathrm{e}^{19}$ się nie kończy. Producenci, a wraz z nimi twórcy reklam, podejmują bowiem karkołomne próby, celem których jest wynalezienie „eliksiru młodości”. Stąd też chcąc sprostać odwiecznemu dążeniu ludzkości do nieśmiertelności, ogłaszają, od czasu do czasu, mniejsze lub większe zwycięstwa, które rzekomo przybliżają człowieka do zdobycia tego nieosiagalnego ideału. Jakże mamy nie wierzyć tym śmiałym zapewnieniom, skoro niemal we wszystkich czasopismach kobiecych powszechne są zapewnienia podobne do tego, jakim posługuje się firma L'Oreal Paris: bądź „zawsze młoda z L'Oreal Paris - ponieważjesteś tego warta" ${ }^{\prime 20}$.

Kobiece ciała ${ }^{21}$ są stale oglądane, zestawiane, porównywane i oceniane. To kobiety od dzieciństwa obserwuja, podziwiają i naśladują inne kobiety. Nie powinien zatem dziwić fakt, iż to właśnie

${ }_{13}$ Z. Bauman, Ciało i przemoc w obliczu ponowoczesności, Torun 1995, s. 90.

14 W. Klimczyk, Erotyzm..., dz. cyt., s. 102.

15 Tamże.

16 Tamże, s. 98.

17 E. Zierkiewicz, I. Kowalczyk, Konsumentka czy konsumowana? Kobieta do zjedzenia w prasie kobiecej, „Kultura Popularna" 2002 , nr 2, s. 119 .

18 N. Etcoff, Przetrwają najpięniejsi. Wszystko, co nauka mówi o ludzkim pięknie, Warszawa 2000, s. 95-96.

19 Specjaliści do spraw reklamy, marketingu, wizerunku.

${ }^{20}$ http://www.lorealparis.pl/_pl/_pl/home/index.aspx, 20.02.2012.

21 Autorka artykułu zdaje sobie sprawę, iż naśladownictwo i „oglądanie ciał” ma miejsce również wśród mężczyzn, jednakże utożsamianie ciała z wizerunkiem w głównej mierze dotyczy kobiet, potwierdzeniem czego jest ilość produktów i usług kosmetycznych skierowanych do pań, a także częstotliwość emisji reklam których są „bohaterkami”. 
panie wkładają więcej trudu w zachowanie młodego, atrakcyjnego wyglądu. Zadręczają się z powodu różnych niedoskonałości, co z powodzeniem wykorzystują agencje reklamowe, nie szczędzące wysiłków by wmówić kobietom, iż dbanie o siebie - rozumiane jako zapobieganie starości, odmładzanie - jest obowiązkiem. Obowiązkiem, którego niedopełnienie bywa postrzegane równoznacznie z „grzechem" zaniedbania, a w najlepszym wypadku świadczy o nieodpowiedzialności, czy też braku silnej woli bądź motywacji. Potwierdzeniem powyższej tezy jest rozpowszechniana w poradnikach dla pań opinia, iż „,kobieta do 35 roku życia ma taką twarz, jaką obdarzyła ją natura, natomiast po 35 roku życia ma taką twarz, na jaką zapracowała sobie sama"22. Dbanie o wizerunek jest więc świadomą strategia, celem której jest przejęcie kontroli nad ciałem poprzez: usuwanie zmarszczek, siwych włosów, liczenie kalorii, stosowanie różnego rodzaju diet, preparatów i balsamów.

Doświadczanie ciała, rozpatrywane w optyce starości, zasadza się więc na permanentnej kontroli, przymusie ciagłego dostosowywania się do społecznych oczekiwań, braku akceptacji i w pewnym sensie zaprzeczaniu własnej cielesności, jakie dokonuje się poprzez jej ustawiczną negację. Ciało człowieka starego jawi się więc w pewnym sensie, jako zapomniany, dawno nieużywany instrument, który z konieczności musi być właściwie dostrojony do melodii dominującej-kultu młodości. Wzrost poziomu kontroli, jaką społeczeństwo współczesne sprawuje nad pojedynczym ciałem sprawia, iż w pewnym sensie jego wizerunek staje się kwestią publiczną. Przekształcając się w ujednolicony i odprywatniony twór, ciało staje się coraz bardziej podatne na wpływy i oczekiwania estetycznie zorientowanego społeczeństwa ${ }^{23}$. Zasadnym wydaje się więc twierdzenie, iż zredukowana wyłącznie do powierzchni soma nie jest człowiekowi dana, lecz zadana jako projekt estetyczno-wizerunkowy, nawet, a może przede wszystkim, wtedy, gdy dotyczy ciała człowieka starego.

Ponowoczesność, jak wskazuje W. Klimczyk, „jest epoką estetyzacji i egzaltacji, a więc szukania w życiu możliwości jak najsilniejszego przeżywania świata"24, czasem, w którym liczy się tylko to, co „estetycznie poprawne”, a zatem ukierunkowane na zmysły. Społeczeństwo przełomu XX i XXI w. jest społeczeństwem obrazów, które coraz częściej kształtują ludzką wrażliwość i ogląd świata. Społeczeństwem, które oszołomione widokiem ciał młodych i pięknych, chce zapomnieć o eschatologii i przykrej świadomości starzenia się i śmierci. W tym celu usuwa się z przestrzeni publicznej (a także z życia codziennego) wszystko to, co kojarzy się z przemijaniem ciała, a więc choroby, starość, kalectwo i śmierć. Ciało w XXI w. przybiera zatem postać estetycznie zorientowanego „przedsięwzięcia”, w optyce którego nie ma miejsca na takie zjawiska jak starzenie się, bowiem wszelkiego rodzaju „odchylenia od estetycznej normy” bywają postrzegane jako swoiste „patologie”, które należy marginalizować, ukrywać lub poddawać obróbce. Jak zauważa W. Klimczyk w ponowoczesności „złe jest to, co źle wygląda”25, dlatego też starość, przywodząca na myśl obraz starego, słabnącego ciała, powinna być upiększana, bądź zamykana: w szpitalach, hospicjach, domach spokojnej starości. Nie wpisuje się w zdeterminowany przez tymczasowość, spontaniczność, piękno i młodość kontekst epoki, dlatego też musi ulec daleko idącym zmianom, dzięki którym zostanie zamaskowana, czy wręcz ukryta pod grubą warstwą makijażu, kremów przeciwzmarszczkowych, balsamów, czy farb do włosów. Przez chirurgów plastycznych „wygładzona”, „wycięta”, „odessana”, przez stylistów „przebrana” a lekarzy „,wyleczona”, wszystko po to, by przestała „straszyć” widmem nieatrakcyjności a, w dalszej konsekwencji, także skończoności.

Magdalena Środa słusznie zauważa, że dziś właściwie nie powinno być starych ludzi, mamy bowiem do swojej „dyspozycji wszelkie narzędzia, zwłaszcza zaś wszelkie nadzieje na wieczną mło-

22 http://ekozdrowie.blog.onet.pl/Jak-walczyc-ze-staroscia,2,ID421960627,n, 20.02.2012.

23 Ciało sytuuje się na pograniczu tego, co prywatne - ciało biologiczne i tego, co społeczne - ciało jako wizerunek.

24 W. Klimczyk, Erotyzm..., dz. cyt., s. 62.

25 Tamże, s. 64. 
dość, a nawet - nieśmiertelność cielesną. Wszystko można obecnie przyciąć, podźwignąć, odessać, podwiązać, zamalować, przykryć, zatuszować, wzbogacić, wymasować, uwilgotnić, przyklepać, dosztukować, odchudzić, odciaggnąć, przylepićn ${ }^{\prime \prime 2}$. Ciało w coraz większym stopniu staje się więc płaszczyzną negocjacji, kwestią wyboru mniej lub bardziej zamierzonego i przemyślanego, stąd też jego permanentne rekonstruowanie nie może być działaniem przypadkowym.

Ciało i jego wizerunek, jako najbardziej zewnętrzna część naszej osobowości, jest obszarem wystawionym na publiczny ogląd i krytykę, swoistym medium, za pośrednictwem którego zmiany zachodzące wewnątrz organizmu dostrzegalne są także na jego powierzchni. To ono się starzeje, choruje, słabnie, obumiera; ono modyfikuje swoją formę i kształt, sygnalizując niepokojące zmiany, przywołujące na myśl tabuizowaną współcześnie śmierć. Warto jednak mieć na uwadze fakt, że starość, pomimo iż w sposób najbardziej dostrzegalny manifestuje się na zewnątrz ciała, dotyczy człowieka jako całości, a zatem istoty psychofizycznej nie dającej się zredukować wyłącznie do wymiaru biologicznego. Stąd też starzenie się istoty ludzkiej (będącej bytem ontologicznie zróżnicowanym), poniekąd z konieczności, musi być rozpatrywane na płaszczyźnie dwóch poziomów ontycznych: materialnego i psychicznego, o czym zdają się zapominać - stanowiące kontekst powyższych rozważań - media masowe.

Fenomen starzenia się, jak powszechnie wiadomo, dokonuje się na przecięciu natury i kultury której „zadaniem wcalenie wybranym dobrowolnie, jest utrwalenie przygodności”27 ludzkiego życia. Jest faktem o dwoistej postaci - u swych podstaw biologicznym, przyobleczonym jednak $\mathrm{w}$ „,kulturową szatę". To dzięki kulturze powstają jego zróżnicowane reprezentacje, będące swoistą inspiracją dla mediów, które nie ustają w poszukiwaniu coraz „atrakcyjniejszych” sposobów wizualizowania starości. Wspomniane uatrakcyjnianie przejawów starzenia, zasadza się przede wszystkim na takim „posługiwaniu się" ciałem, by uzyskało ono akceptowalny dla danej społeczności wygląd. Media, jak powszechnie wiadomo, jednocześnie kulturę odzwierciedlają i kreują nie przedstawiają świata wprost, lecz próbują go konstruować poprzez nadawanie własnych sensów i znaczeń. W efekcie tego, także starość bywa zapośredniczana przez dyskurs medialny. Warto jednak nadmienić, iżjest to starość specyficznego rodzaju, starość przetworzona, poddana swoistemu liftingowi. Zestetyzowana i odmłodzona, innymi słowy „uszyta na miarę” oczekiwań współczesności.

Fundamentalne doświadczenie człowieka XXI w. to spotkania z obrazami, które regulowane są przez rynek, co - jak zauważa W. Klimczyk - musi mieć skutki praktyczne ${ }^{28}$. Manipulacja obrazami, którą zaobserwować można m.in. na przykładzie reklam sprawia, iż ludzkie pragnienia i potrzeby są ustawicznie przemodelowywane, szczególnie zaś te, które koncentrują się na wizerunku. Media masowe rozbudzają pragnienia i oczekiwania odbiorców do granic możliwości, przekonując jednocześnie, iż w kontekście ciała wszystko jest możliwe. Ciało w dyskursie medialnym percypowane jest jako powierzchnia, którą w dowolny sposób można zapisywać, kreować i stwarzać. To wizerunek interpretowany jako sposób, w jaki indywidualne ciało chce być widziane przez inne ciała. Nie bez powodu zatem media masowe stale pobudzają męskie i kobiece oczekiwania względem ciał, insynuuja, że wszystko (i dla wszystkich) w tej materii jest możliwe, wystarczy silna wola i chęci. Estetycznie zorientowana ponowoczesność domaga się więc, by człowiek uznał swoje ciało za swoisty projekt, wymagający ciagłych starań i pracy ukierunkowanej na przekształcanie go w „dzieło sztuki”, po-

${ }_{26}$ Środa M., Nie udo, ale gałą́ sucha, „Biuletyn OŚKi” 2000, nr 4, s. 2, http://www.oska.org.pl/biuletyn/10/96.pdf, 15.02.2012.

27 Z. Bauman, Śmierć i nieśmiertelność. O wielości strategii życia, Warszawa 1998, s. 31.

28 W. Klimczyk, Erotyzm..., dz. cyt., s. 63-64. 
nieważ - jak zauważa W. Klimczyk - „ciało powinno być wiecznie gotowe by się prezentować"29, bowiem miarą jego sukcesu jest ilość pożądliwych spojrzeń.

Starość, postrzegana przede wszystkim z punktu widzenia cielesności, jawi się zatem jako swoisty problem. Jednocześnie jednak, dostrzeżona przez media i szeroko rozumiany rynek dóbr i usług, przyczynia się do przekształcania seniorów w niezwykle atrakcyjną grupę konsumentów, nie do końca jednak zagospodarowaną. Nie jest odkrywczym stwierdzenie, iż obserwowany wzrost zainteresowania twórców reklam wizerunkiem i kondycją seniorów podyktowany jest wyłącznie względami ekonomicznymi, nie zaś troską o jakość życia najstarszej z grup społecznych. Idea utrzymywania ciała w dobrej formie fizycznej to dzisiaj potężny przemysł zarabiający miliony na niezadowolonych ze swego wyglądu i stanu zdrowia seniorach. Potwierdzeniem powyższej tezy jest opinia Nancy Etcoff, która zauważa, iż „dziś przeciętna kobieta porównuje swoje odziedziczone po przodkach wyposażenie fizyczne z kilkoma starannie wybranymi modelkami. Mimo że ich uroda jest nierzeczywista, media przekonują nas, że możemy osiągnąć ich piękno, jeśli włożymy w to dużo trudu i zabiegów oraz kupimy odpowiedni produkt $t^{30 \prime}$. Zatem zasadnym wydaje się być stwierdzenie, iż im większa wytrwałość i czujność na zmieniające się trendy, tym większe prawdopodobieństwo sukcesu, którego wymiar jest sprzężony z koniecznością ciągłego uaktualniania wizerunku, ciągłej redefinicji cielesności dostosowanej do stale zmieniających się wzorów.

Nawet powierzchowna analiza reklam pojawiających się w środkach masowego przekazu pozwala wysnuć wniosek, iż jednym ze sposobów ujmowania starości jest jej utożsamianie z ciałem, bądź też poszczególnymi jego fragmentami: „40 lat minęło... a Ty ciąle czujesz się młodo. Twoja skóra też może być długo promienna i gładka” - bądź „zawsze młoda z L’Oréal”, „Walcz z utratą jędrności i widocznymi zmarszczkami”, ponieważ „po 50. roku życia nawilżenie skóry zmniejsza się, jej struktura jest mniej jędrna, a cera staje się mniej jednolita. Nowy krem rewitalizujący na dzień Garniera Orchidea Vital zwalcza główne widoczne oznaki starzenia. Każdego dnia coraz głębsze warstwy skóry są nawilżone, dzięki czemu wygląda ona na odbudowaną i promienną. Kobiety zauważają efekty działania produktu już po 4 tygodniach stosowania" ${ }^{\prime \prime}$. Multiplikowane w mediach masowych ciało przedstawia się zatem jako organ niezwykle plastyczny, otwarty na różnego rodzaju sygnały, które jednostka wchłania, czerpie, asymiluje, konsumuje. Jest ono swoistym medium, powierzchnia, na której odbywają się „negocjacje” pomiędzy światem zewnętrznym i wewnętrznym.

Wizerunki ciał naturalnie się starzejących są coraz usilniej marginalizowane, wręcz wypierane ze świadomości i wyobraźni. Do publicznego oglądu dopuszczane są bowiem wyłącznie te przedstawienia, które reprezentują obraz starości aktywnej, pełnej wigoru i życiowej energii. W efekcie, ciała zdradzające objawy starzenia traktowane są jak coś, co w pewnym sensie wymyka się kontroli i jako takie stanowi potencjalne zagrożenie -,„ściąga na siebie siły moralne, prawne, estetyczne, które mają za zadanie to coś zdyscyplinować ${ }^{\prime \prime 2}$. Ciało bowiem, jak zauważa Z. Bauman ,jest dziś, w sposób nie podlegający dyskusji »własnością prywatną«. Jego kultywowanie, jak uprawa ogródka działkowego, jest sprawą właściciela. Nie ma kogo, poza właścicielem, ganić, jeśli ogród porośnie chwastami, gleby nie użyźni się jak trzeba, a w konewce wody zabraknie (...). Uzyskawszy swe ciało na własność, znalazł się jednak właściciel w tarapatach nie lada. Jest przecież ogrodem i ogrodnikiem naraz"33.

29 Tamże, s. 109 .

30 N. Etcoff, Przetrwaja..., dz. cyt., s. 97.

31 http://e-styl.com/p/pl/5486/garnier+orchidea+vital+-+wiek+50+krem+rewitalizujacy+na+dzien+50+ml.html, 12.02.2012.

32 J. Fiske, Zrozumieć kulture popularna, Kraków 2010, s. 73.

33 Z. Bauman, Ciało..., dz. cyt., s. 94. 


\section{Bibliografia:}

Bauman Z., Ciało i przemoc w obliczu ponowoczesności, UMK, Torun 1995.

Bauman Z., Śmierć i nieśmiertelność. O wielości strategii życia, PWN, Warszawa 1998.

Bois J. P., Historia starości od Montaigne'a do pierwszych emerytur, Volumen, Warszawa 1996.

Czaja D., Reklamowy smak raju: między archetypem i historia, [w:] tenże (red.), Mitologie popularne, Universitas, Kraków 1994.

Etcoff N., Przetrwają najpiękniejsi. Wszystko, co nauka mówi o ludzkim pięknie, WAB, Warszawa 2000.

Fiske J., Zrozumieć kulturę popularna, Wydawnictwo Uniwersytetu Jagiellońskiego, Kraków 2010.

Klimczyk W., Erotyzm ponowoczesny, Universitas, Kraków 2008.

Minois G., Historia starości. Od antyku do renesansu, Volumen, Warszawa 1995.

Zierkiewicz E., Kowalczyk I., Konsumentka czy konsumowana? Kobieta do zjedzenia w prasie kobiecej, „,Kultura Popularna” 2002, nr 2.

\footnotetext{
NetOGRAFia:

Nieinwazyjna kuracja odmładzająca bezpieczniejsza od zastrzyków i chirurgii plastycznej, http://frownies.pl/frownies.html, 20.02.2012. Środa M., Nie udo, ale gałaź sucha, „Biuletyn OŚKi” 2000, nr 4, http://www.oska.org.pl/biuletyn/10/96.pdf, 15.02.2012. Zielono mi ...!, http://ekozdrowie.blog.onet.pl/Jak-walczyc-ze-staroscia,2,ID421960627,n, 20.02.2012.

http://e-styl.com/p/pl/5486/garnier+orchidea+vital+-+wiek+50+krem+rewitalizujacy+na+dzien+50+ml.html, 12.02.2012. http://ibeauty.pl/artykuly,146,148,2298,polecamy-na-prezent-zestawy-olay-total-effects, 20.02.2012.

http://www.avene.com.pl/dermokos.php?dnavi=6\&pm=p-ystheal\&ind=0, 20.02.2012.

http://www.cogiel-medicalspa.pl/oferta/pielegnacja-ciala/, 20.02.2012.

http://www.lorealparis.pl/_pl/_pl/home/index.aspx, 20.02.2012.
}

\section{STRESZCZENIE}

W każdej epoce dostrzegamy odmienny stosunek człowieka do starości, przemijania i ludzi starych, wyrazem którego są zróżnicowane postawy i wyobrażenia na temat tego specyficznego okresu życia. Rzeczywistość XXI w., określana mianem „wzrokocentrycznej”, zdominowana została przez kult piękna i młodości, w efekcie czego, przed ciałem - szczególnie zaś ciałem człowieka starego - stawiane są coraz radykalniejsze oczekiwania, oscylujące wokół zagadnień związanych z atrakcyjnym wizerunkiem. Obserwowany współcześnie wzrost ilości osób starszych w ogólnej liczbie ludności sprawił, iż seniorzy są coraz uważniej obserwowaną grupą społeczną. Zapośredniczane przez dyskurs medialny wizerunki seniorów stają się zatem coraz powszechniejsze, stąd też podjęta przez autorkę artykułu próba rekonstrukcji ponowoczesnych strategii obrazowania późnej dorosłości, jawi się jako szczególnie interesujący i ważny obszar refleksji.

Słowa kluczowe: starość, ciało, media, reklama, wizerunek, estetyzacja.

\section{Aging in the CUlture of yOUTH. Selected STRATEgies OF THE LATE ADULTHOOD IMAGING IN ADVERTISING}

\section{Summary}

In every epoch we can notice a different human's attitude towards the old age, fading away and the old people which manifests itself in distinct attitudes and ideas about this specific life's period. The "visual reality" of XXI age worships the beauty and the youth. This fact entails more and more radical social expectations about appearance. The body, especially the old men's one, should be attractive. Nowadays there's a noticeable increase in the total number of the elders. They become therefore an attentively observed society class. In the mass media, the "appealing" old men's images are becoming more and more popular and common, so the reflections on this subject perceive as an interesting and important area of investigations. This article is an attempt to reconstruct a "post-modern" strategies of creating and showing the old age images.

Key words: the old age, body, the mass media, commercial, image, aesthetics 